Original Research Paper

\title{
Utilization of Biduri Juice (Calotropis gigantea) in The Process of Buffalo Milk Coagulation on Quality of Soft Cheese
}

\author{
Bulkaini $^{1 *}$, B.R.D. Wulandani ${ }^{1}$, IN. S. Miwada ${ }^{2}$, Twenfosel O. Dami Dato ${ }^{3}$, Liana Dewi ${ }^{4}$ \\ ${ }^{1}$ Faculty of Animal Husbandry, University of Mataram Jalan Majapahit No.62 Mataram West Nusa Tenggara. \\ ${ }^{2}$ Faculty of Animal Husbandry, Udayana University, Kampus Bukit Jimbaran, South Kuta District, Badung Regency, \\ Bali 80361 \\ ${ }^{3}$ Faculty of Animal Husbandry, University of Nusa Cendana, Jalan Adisucipto Penfui, Kupang Nusa Tengara Timur. \\ ${ }^{4}$ Graduates of the Faculty of Animal Husbandry, University of Mataram Jalan Majapahit No.62 Mataram West Nusa \\ Tenggara
}

\section{Article History}

Received : November $30^{\text {th }}, 2020$

Revised : December $08^{\text {th }}, 2020$

Accepted : December $10^{\text {th }}, 2020$

Published : December $18^{\text {th }}, 2020$

*Corresponding Author:

Bulkaini,

Faculty of Animal Husbandry, University of Mataram Jalan

Majapahit No.62 Mataram West

Nusa Tenggara, Indonesia;

Email: b_kaini@yahoo.com

\begin{abstract}
Cheese is a processed product with a basic ingredient in the form of milk which is produced by separating solid substances in milk through a coagulation process. Soft cheese is cheese with a moisture content of 45$80 \%$. Research aims to know the benefits of biduri juice in the manufacture of buffalo milk soft cheese. In an effort to determine the benefits of the biduri juice an experimental method was carried out using a Randomized Block Design (RBD).The study consisted of two groups, namely K1 which was made of cheese using $0.02 \mathrm{ml} / 2$ liter of rennet milk, while $\mathrm{K} 2$ was made of cheese using $0.6 \mathrm{cc} / 2$ liter of biduri sap milk. The cheese produced on K1 and $\mathrm{K} 2$ was stored for 0 days, 12 days and 24 days as treatment. The results of the study which consisted of protein, fat and water levels were analyzed using analysis of variance based on a Randomized Block Design (RBD) using the SPSS version 16 program and continued with the Duncant test with a confidence level of 5\%. The results showed that the use of biduri juice 0.6 $\mathrm{cc} / 2$ liters of milk in cheese making produced cheese with protein content ranging from $22.74-23.85 \%$ higher than the use of rennet at $21.99-23.65 \%$. Fat content of cheese with biduri juice coagulation resulted in fat content ranging from $0.59-0.84 \%$ lower than using rennet ranging from $0.8-1.04 \%$. The water content of soft cheese coagulated with biduri juice and rennet is still in the normal range of water content set by the United States Department of Agriculture (USDA), which is not more than $80 \%$. Based on the results of the study, it can be concluded that the use of biduri juice at the level of 0.6 cc / 2 liters of fresh buffalo milk in making soft cheese with a storage time of 0 days, 12 days and 24 days, it can produce protein and fat content of soft cheese that meets SNI with water content of cheese according to USDA standards, namely not exceeding $80 \%$.
\end{abstract}

Keywords: Biduri Juice, Soft Cheese and Buffalo Milk.

\section{Pendahuluan}

Kerbau adalah ternak penghasil susu kedua di dunia setelah sapi perah (Coroian et al., 2013) dan menghasilkan susu berkualitas tinggi (Senosy dan Hussein, 2013). Susu kerbau biasanya digunakan untuk memproduksi keju, khususnya keju mozzarella (Aspilcueta-Borquis et al., 2012). Keju yang terbuat dari susu kerbau memiliki tekstur yang khas dan kualitas sensoris superior (Hofi, 2013). Yilmaz et al. (2012) melaporkan produksi susu kerbau berkisar antara 24-26 liter/hari selama periode laktasi $225 \pm 6$ hari. Total padatan susu kerbau adalah $17,7 \pm 0,3 \%$, protein $4,2 \pm 0,1 \%$, dan lemak $8,1 \pm 0,2 \%$. Dengan mempertimbangkan semua elemen tersebut, produksi susu kerbau $40 \%$ lebih banyak dibanding susu sapi (Andrade et al., 2009) dan harga susu kerbau sekitar tiga kali lipat dari susu sapi (Rosati dan Van Vleck, 2002).

Kerbau yang banyak dipelihara masyarakat Indonesia adalah kerbau rawa/lumpur yang bukan tipe perah, tetapi di beberapa daerah peternak melakukan pemerahan. Potensi populasi 1,4 juta ekor kerbau di Indonesia dapat dimanfaatkan untuk meningkatkan ketersediaan susu nasional. Di Nusa Tenggara Barat (Sumbawa), produksi susu kerbau rawa/lumpur bervariasi antara 1,5-2,17 liter/ekor/hari (Muthalib, 2006). Zulbardi (2002), dalam penelitiannya menunjukkan produksi susu kerbau rawa/lumpur berkisar antara 1,50-2,50 liter/ekor/hari dengan masa laktasi sekitar 7 bulan.

Kandungan lemak susu kerbau berkisar antara $7-8 \%$ dan protein $4,2-4,6 \%$, sedangkan sapi zebu masing-masing $4 \%$ dan $3,5 \%$, yang menunjukkan 
susu kerbau lebih baik dari pada susu sapi zebu. Han et al.(2012), menyatakan bahwa kadar protein,lemak, mineral, dan vitamin susu kerbau lebih baik dari pada susu sapi. Kualitas susu dipengaruhi oleh faktor genetik dan lingkungan terutama bangsa kerbau dan pakan (Otaviano et al., 2005). Susu kerbau juga lebih kaya akan kandungan mineral penting yaitu Ca $92 \%$, $\mathrm{Fe} 38 \%$, dan $\mathrm{P} 118 \%$, kandungan kolesterol lebih rendah $(0,65 \mathrm{mg} / \mathrm{g})$ dari pada susu sapi $(3,14 \mathrm{mg} / \mathrm{g})$ serta kandungan vitamin A lebih tinggi (Febrina, 2010).

Susu kerbau, seperti halnya susu sapi dapat diproses menjadi berbagai macam produk seperti keju, mentega, es krim, yoghurt dan buttermilk. Dalam menghasilkan produk yang sama, jumlah susu kerbau yang dibutuhkan lebih sedikit dari pada susu sapi, yaitu untuk membuat $1 \mathrm{~kg}$ keju dibutuhkan $8 \mathrm{~kg}$ susu sapi atau hanya $5 \mathrm{~kg}$ susu kerbau dan untuk membuat $1 \mathrm{~kg}$ mentega dibutuhkan $14 \mathrm{~kg}$ susu sapi atau $10 \mathrm{~kg}$ susu kerbau (Anonim, 2011).

Pada proses pembuatan keju di Indonesia masih mengimport enzim rennet dari negara-negara di benua Eropa, oleh sebab itu perlu di cari alternatif sebagai pengganti penggunaan enzim rennet dalam pembuatan keju sehingga dapat menekan biaya produksi keju lunak. Salah satu bahan lokal yang berpotensi sebagai pengganti enzim rennet adalah getah dari tanaman biduri (Calotropis gigantean). Menurut Witono (2007), ekstrak protease tanaman biduri baik dari getah, batang, maupun dari daun sangat potensial sebagai sumber enzim protease. Biduri merupakan jenis tumbuhan semak liar tropis yang populasinya cukup melimpah, tumbuh pada lahan kering dan areal sekitar pantai. Protease sendiri merupakan enzim penghidrolisa protein yang banyak digunakan dalam industri pangan, seperti pembuatan keju, penjernih bir, pembuatan roti, pengempuk daging, hidrolisa protein, ekstraksi minyak dan sebagainya

Susanti (2005), menyatakan bahwa suhu optimum enzim protease biduri adalah $55^{\circ} \mathrm{C}$ dengan aktivitas enzim sebesar 0,077 unit aktivitas/mg protein enzim. $\mathrm{pH}$ optimum enzim adalah $\mathrm{pH} 7$ dengan aktivitas sebesar 0,091 unit aktivitas/mg protein enzim, sedangkan daya tahan enzim terhadap panas dapat bertahan pada suhu $60^{\circ} \mathrm{C}$ dan di atas suhu $80^{\circ} \mathrm{C}$ enzim mengalami inaktivasi. Kecepatan maksimum enzim protease biduri sebesar $18,867 \mathrm{mg} / \mathrm{ml} / \mathrm{min}$. Wulandani (1995) menyatakan bahwa penggunaan getah biduri (Calotropis gigantea) untuk menggumpalkan susu secara tradisional mendapatkan bahwa dengan dosis 0,2-0,8 cc getah/liter susu memberikan rasa yang gurih akan tetapi dengan meningkatkan dosis menjadi 1,6 cc/liter mulai menimbulkan rasa pahit. Berdasarkan uraian-uraian di atas dilakukan penelitian dengan judul: Pemanfaatan Sari Getak Biduri (Calotropis gigantea) Dalam Proses Penggumpalan Susu Kerbau Terhadap Kualitas Keju Lunak.

\section{Materi dan Metode}

\section{Pembuatan sari getah biduri}

Getah biduri (Calotropis gigantea) diperoleh dengan memotong bagian ujung batang atau ranting pohon biduri. Getah biduri disaring dengan kain saring untuk memisahkan sari dengan gumpalan getah.

\section{Perbanyakan starter culture}

Susu segar sebanyak $500 \mathrm{ml}$ dimasukkan ke dalam 2 erlenmayer, masing erlenmayer berisi $250 \mathrm{ml}$. Susu dipasturisasi pada suhu $60-65^{\circ} \mathrm{C}$ selama 10 detik. Setelah 10 menit proses pasturisasai dihentikan sambil dilakukan penurunan suhu menjadi $45^{\circ} \mathrm{C}$. Pada masing-masing erlenmayar dilakukan proses inokulasi bakteri Streptococcus thermophillus dan Lactobacillus bulgaricus masing-masing 2\% dari volume bahan baku, selanjutnya hasil inokulasi disimpan pada suhu runag selama 24 jam.

\section{Perlakuan dalam pembuatan keju}

Susu kerbau sebanyak 12 liter dibagi menjadi 2 kelompok: K1= 6 liter susu segar ditambahkan dengan rennet komersial 0,02 ml/2 liter susu dan $\mathrm{K} 2=$ 6 liter susu segar ditambahkan dengan sari getah biduri $0,6 \mathrm{cc} / 2$ liter susu. Keju yang dihasilkan pada masing-masing kelompok dilakukan penyimpanan dengan lama yang berbeda-beda yaitu 0 hari, 14 hari dan 28 hari sebagai perlakuan dan tiap perlakuan diulang 4 kali. Diagram alir pembuatan keju terlihat pada Gambar 1. 


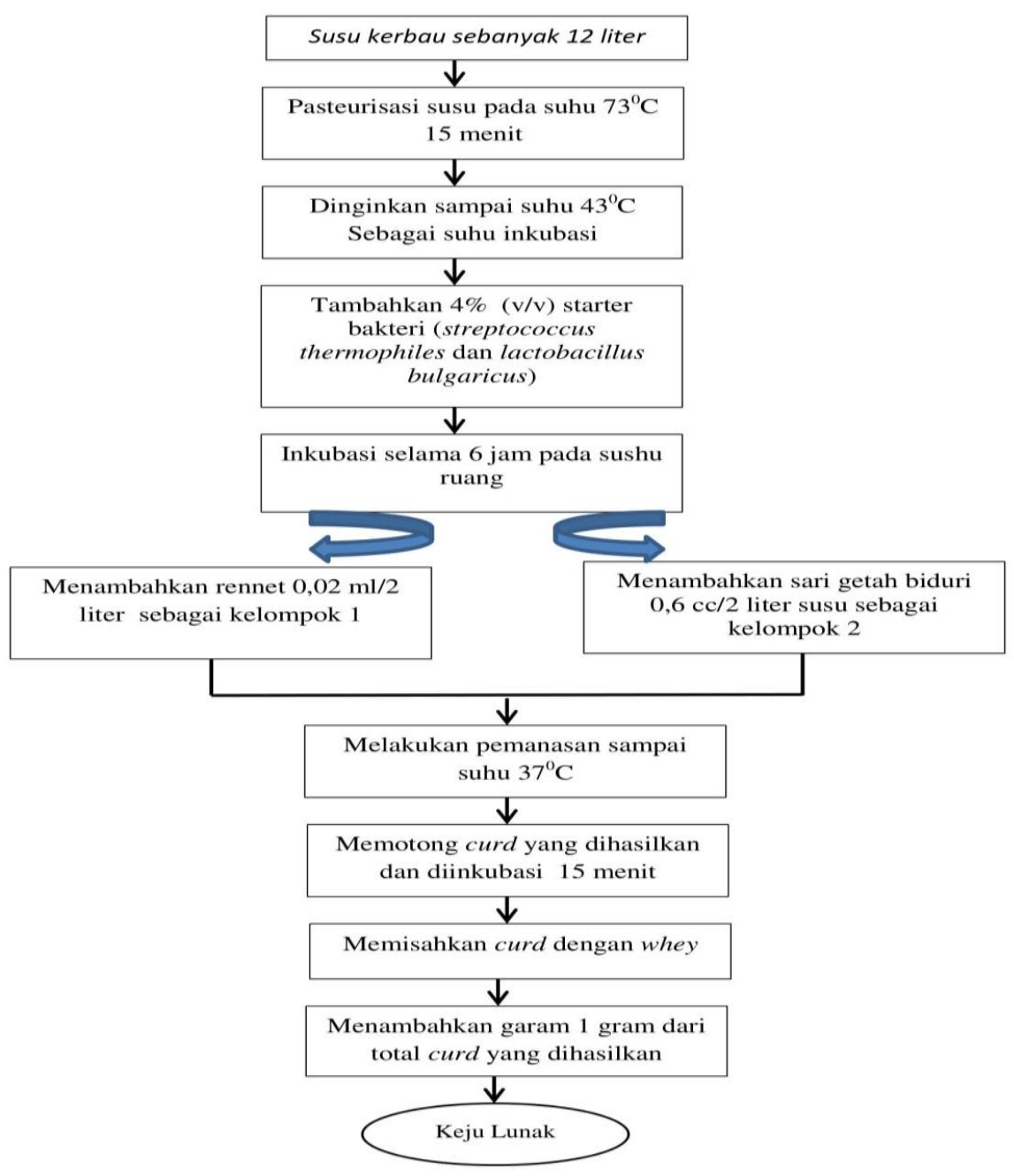

Gambar 1. Diagram alir pembuatan keju lunak

\section{Varibel penelitian}

Kadar protein diukur menggunakan metode mikro Kjeldahl, kadar lemak dengan cara ekstraksi langsung dengan alat soxhlet (AOAC, 2010) dan kadar air ditetapkan dengan metode pemanasan (Sugitha et al., 2016).

\section{Analisa Data.}

Hasil penelitian di analisa dengan analisa varian berdasarkan Rancangan Acak Kelompok (RAK) dengan program SPSS versi 16 dan dilanjutkan dengan uji jarak Ganda Duncant Multiple Range Test pada tingkat kepercayaan 5\% (Steel and Torrie, 2015).

\section{Hasil Dan Pembahasan}

\section{Kadar protein keju lunak}

Hasil analisa varian menunjukkan bahwa lama penyimpanan keju berpengaruh nyata $(\mathrm{P}<0,05)$ terhadap kandungan protein keju lunak baik pada keju lunak dengan penambahan rennet $0,02 \mathrm{ml} / 2$ liter susu maupun keju lunak dengan penambahan sari getah biduri $0,6 \mathrm{ml} / 2$ liter susu. Hasil uji Duncant menunjukkan bahwa protein keju lunak dengan penambahan sari getah biduri $0,6 \mathrm{cc} / 2$ liter susu pada penyimpanan nol hari=H0 $(22,74 \%)$ tidak berbeda nyata $(0>0,05)$ dengan 12 hari=H12 $(23,15 \%)$, tetapi berbeda nyata $(\mathrm{P}<0,05)$ dengan 24 hari $=\mathrm{H} 24$ $(23,85 \%)$. Selanjutnya antara H12 $(23,15 \%)$ tidak berbeda nyata( $\mathrm{P}>0.05)$ dengan $\mathrm{H} 24(23,85 \%)$. Protein keju lunak dengan penambahan rennet $0,02 \mathrm{ml} / 2$ liter susu antara $\mathrm{H} 0(21,99 \%)$ tidak berbeda nyata $(\mathrm{P}>0,05)$ dengan $\mathrm{H} 14(22,16 \%)$, tetapi berbeda nyata $(\mathrm{P}<0,05)$ dengan $\mathrm{H} 24(23,65 \%)$, selanjutnya antara $\mathrm{H} 12(22,16 \%)$ berbeda nyata $(\mathrm{P}<0,05)$ dengan $\mathrm{H} 24(23.65 \%)$. Hasil penelitian (Gambar 1) memperlihatkan bahwa keju yang disimpan selama 24 jam baik pada keju lunak yang digumpalkan dengan sari getah biduri maupun dengan rennet mengandung protein yang lebih tinggi dibandingkan dengan perlakuan tanpa penyimpanan (0 hari) dan penyimpanan 12 hari yaitu masing-masing $23,85 \%$ dan $23,65 \%$. Peningkatan kandungan protein ini disebabkan karena dengan semakin lama 
penyimpanan menyebabkan kerja dari enzim protease yang terkandung dalam sari getah biduri maupun dalam rennet menyebabkan aktivitasnya semakin sempurna sehingga proses pemecahan peptida dari unsur penyusun protein mengalami pemecahan yang sempurna.

Kadar protein keju lunak yang dihasilkan dengan penambahan getah biduri lebih tinggi dibandingkan dengan kadar protein yang dihasilkan dengan penambahan rennet baik pada penyimpanan 0 hari, 12 hari maupun 24 hari (Gambar 1). Hal ini disebabkan karena pada perlakuan dengan penambahan getah biduri, protein keju selain berasal dari kandungan protein susu itu sendiri juga berasal dari sari getah biduri yang digunakan sebagai media penggumpal susu. Witono et al. (2007) mengatakan bahwa getah biduri mempunyai kadar protein protease yang tinggi yaitu mencapai $45 \%$ jika diekstraksi dengan amonium sulphat $65 \%$.

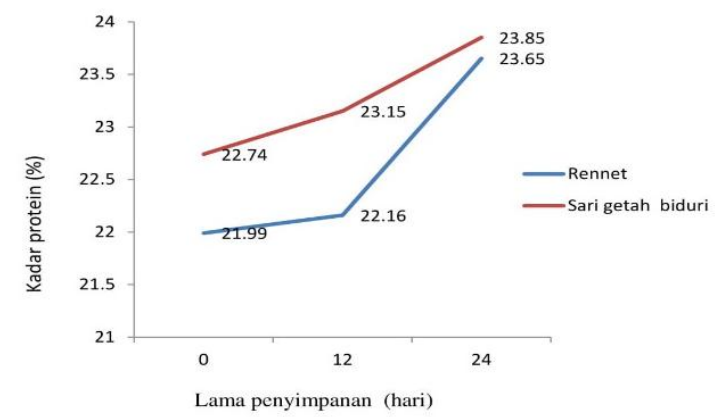

Gambar 1. Kandungan protein keju lunak berdasarkan lama penyimpanan

Mustrini et al. (2016) menyatakan bahwa ekstrak dari tanaman biduri baik getah, batang maupun daun sangat potensial sebagai sumber enzim protease yang sangat bermanfaat dalam pengolahan pangan misalnya dalam pembuatan keju. Lebih lanjut dikatakan enzim protease sangat berperan dalam memecah ikatan protein menjadi peptida. Penggunaan getah biduri yang semakin banyak akan meningkatkan konsentrasi dan aktivitas enzim protease getah biduri dalam memecah ikatan protein menjadi peptida sehingga dapat meningkatkan kandungan protein keju. Kadar protein keju lunak yang dihasilkan dalam penelitian ini $(23,85 \%)$ tidak jauh berbeda dengan kadar protein keju yang dihasilkan oleh Geantaresaa et al. (2010) yang menggunakan ekstrak kasar papain yaitu sebesar yaitu 28,04\%. Menurut saleh (2004), faktor yang berpengaruh terhadap kandungan protein keju antara lain kandungan protein susu segar dan jenis bakteri asam laktat yang digunakan. Susu kerbau segar mempunyai kandungan protein 5,50\% lebih tinggi dibandingkan dengan kadar protein susu sapi segar $(3,50 \%)$ sehingga setelah diolah menjadi keju lunak akan memberikan protein yang lebih tinggi. Proses pembuatan keju yang menggunakan jenis bakteri asam yang laktat lebih dari satu sebagai starter dalam proses inokulasi akan menghasilkan keju lunak dengan kandungan protein yang maksimal.

\section{Kadar lemak keju lunak}

Hasil analisa varian menunjukkan bahwa lama penyimpanan keju berpengaruh nyata $(\mathrm{P}<0,05)$ terhadap kandungan lemak keju baik pada keju lunak dengan penambahan rennet $0,02 \mathrm{ml} / 2$ liter susu maupun keju lunak dengan penambahan sari getah biduri $0,6 \mathrm{cc} / 2$ liter susu. Hasil uji Duncant menunjukkan bahwa lemak keju lunak dengan penambahan sari getah biduri $0,6 \mathrm{cc} / 2$ liter susu pada penyimpanan $\mathrm{HO}(0,84 \%)$ berbeda nyata $(\mathrm{P}<0,05)$ dengan $\mathrm{H} 12(0,49 \%)$ dan $\mathrm{H} 24(0,59 \%)$, sedangkan antara $\mathrm{H} 12(0,49 \%)$ tidak berbeda nyata $(\mathrm{P}>0.05)$ dengan H24 (0,59\%). Lemak Keju lunak dengan penambahan rennet $0,02 \mathrm{ml} / 2$ liter susu antara $\mathrm{H} 0(1,04 \%)$ berbeda nyata $(\mathrm{P}<0,05)$ dengan $\mathrm{H} 12(0,84 \%)$ dan $\mathrm{H} 24(0,80 \%)$ sedangkan antara $\mathrm{H} 12(0,84 \%)$ tidak berbeda nyata $(\mathrm{P}>0,05)$ dengan $\mathrm{H} 24(0,80 \%)$. Hasil penelitian (Gambar 2) memperlihatkan bahwa penyimpanan keju lunak yang dihasilkan dengan rennet selama 24 jam menyebabkan lemak keju lunak cenderung menurun yaitu dari $1,04 \%$ menjadi $0,80 \%$, sedangkan penambahan sari getah biduri penuruan lemak keju lunak terjadi pada lama penyimpanan $12 \mathrm{jam}$, setelah penyimpanan diperpanjang menjadi 24 jam lemak keju lunak meningkat dari 0,49 menjadi $0,59 \%$ namun tidak berbeda nyata $(\mathrm{P}>0,05)$.

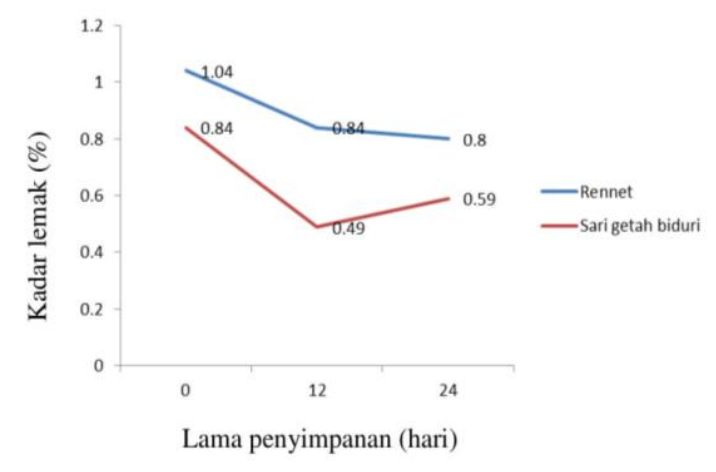

Gambar 2. Kandungan lemak keju lunak berdasarkan lama penyimpanan

Kadar lemak keju lunak yang dihasilkan dengan penambahan getah biduri lebih rendah dibandingkan dengan kadar lemak yang dihasilkan dengan penambahan rennet baik pada penyimpanan 0 hari, 12 hari maupun 24 hari (Gambar 2). Pada gambar 2 terlihat bahwa kadar lemak keju lunak yang dalam proses pembuatannya ditambahkan sari getah biduri $0,6 \mathrm{cc} / 2$ liter susu memberikan kadar lemak keju lunak berkisar 0,49-0,84\%, sedangkan dengan penambahan rennet kadar lemak keju lunak berkisar 0,80-1,04\%. Kadar lemak keju lunak yang dihasilkan dalam penelitian masih dibawah standar kadar lemak keju yang ditetapkan Heller et al. (2008) yaitu 25 - $45 \%$ dan masih juga dibawah standar kadar lemak keju mozzarella menurut SNI yaitu minimal 25\% (Komar et al., 2009). United States Department of 
Agriculture=USDA (2001), menetapkan bahwa kadar lemak untuk cortage Cheese (keju lunak) tidak boleh lebih dari 0,5\%. Komar et al. (2009) menjelaskan bahwa makin tinggi kandungan protein dalam keju, maka makin banyak pula jumlah lemak yang dapat diikat dan dipertahankan dalam keju, sehingga keju yang dihasilkan menjadi tinggi kadar lemaknya. Dengan berpedoman pada SNI, dapat dikatakan bahwa keju yang dihasilkan dalam penelitian ini tidak memmpunyai dampak negatif terhadap kesehatan yaitu tidak meningkatkan kolesterol dalam tubuh.

\section{Kadar air keju lunak}

Hasil analisa varian menunjukkan bahwa lama penyimpanan keju tidak berpengaruh nyata $(\mathrm{P}>0,05)$ terhadap kandungan air keju baik pada keju lunak dengan penambahan rennet $0,02 \mathrm{ml} / 2$ liter susu, sedangkan pada keju lunak dengan penambahan sari getah biduri $0,6 \mathrm{cc} / 2$ liter susu lama penyimpanan berpengaruh nyata $(\mathrm{P}<0,05)$ terhadap kandungan air keju lunak. Hasil uji Duncant menunjukkan bahwa kadar air keju lunak dengan penambahan sari getah biduri $0,6 \mathrm{cc} / 2$ liter susu pada penyimpanan $\mathrm{H} 0(59 \%)$ tidak berbeda nyata $(\mathrm{P}>0,05)$ dengan $\mathrm{H} 12(58,89 \%)$, tetapi berbeda nyata $(\mathrm{P}<0,05)$ dengan $\mathrm{H} 24(57,43 \%)$, sedangkan antara $\mathrm{H} 12(58,89 \%)$ berbeda nyata $(\mathrm{P}<0.05)$ dengan $\mathrm{H} 24 \quad(57,43 \%)$. Hasil penelitian (Gambar 3) memperlihatkan bahwa kadar air keju lunak yang dihasilkan dengan penambahan rennet berkisar 57,76-58,35\%, sedangkan kadar air keju lunak yang dihasilkan dengan penambahan sari getah biduri berkisar 57,43-59\%. Kadar air keju lunak yang dihasilkan dalam penelitian ini lebih tinggi dari ketentuan kadar air keju mozzarella yaitu sekitar 46$56 \%$ (Hiu, 1991) dalam Sunarya (2016) dan berdasarkan Standar Nasional Indonesia (SNI) yaitu sebesar 45\% (Komar et al., 2009). Berdasarkan standar kadar air keju lunak yang ditetapkan oleh Heller et al. (2008), dapat dikatakan bahwa keju yang dihasilkan dalam penelitian ini termasuk dalam katagori keju lunak karena mengandung kadar air lebih dari 55\%. USDA (2001), menetapkan bahwa kadar air untuk keju lunak (cortage Cheese) tidak boleh melebihi $80 \%$. Produk keju yang memiliki kadar air 45-55\% termasuk keju semi lunak, sedangkan yang memiliki kadar air 20-24\% termasuk kejuk keras (Heller et al, 2008).

Keju mozzarella yang baik pada umumnya dihasilkan dari susu kerbau, karena pada dasarnya susu kerbau mengandung lebih banyak lemak dan protein serta rendah kadar airnya (Sari, 2014). Sunarya et al. (2016) menyatakan bahwa tinggi rendahnya kadar air dan kadar lemak dalam keju mozzarella akan menentukan kualitas tekstur keju. Tekstur melukiskan struktur atau kekompakan dari keju. Tekstur keju ada 2 macam yaitu tekstur tertutup dan tekstur terbuka. Tekstur tertutup yaitu keju yang masif yang tidak memiliki lubang-lubang pada tubuhnya sedangkan tekstur yang terbuka adalah keju yang tubuhnya berlubang-lubang. Lubang-lubang pada keju yang berlebihan merupakan suatu cacat pada keju.

\section{Kesimpulan}

Pemanfaatan sari getak biduri pada level 0,6 cc/2 liter susu kerbau segar dalam pembuatan keju lunak dengan lama penyimpanan 0 hari, 12 hari dan 24 hari dapat menghasilkan kadar protein dan lemak keju lunak yang memenuhi ketentuan SNI, dengan kadar air yang memenuhi standar USDA. Sari getak biduri dapat digunakan sebagai pengganti rennet import dalam pembuatan keju lunak susu kerbau. Dalam upaya untuk memproduksi keju lunak dengan protein, lemak dan kadar air yang memenuhi SNI dan USDA, maka dalam proses pembuatannya dapat menggunakan sari getah biduri sebanyak 0,06 cc/2 liter susu.

\section{Ucapan terima kasih}

Terima kasih disampaikan kepada Pimpinan Fakultas Peternakan Universitas Mataram yang telah memberikan ijin untuk melakukan penelitian di Laboratorium Teknologi Pengolahan Hasil Ternak Fakultas Peternakan Universitas Mataram.

\section{Referensi}

Andrade R.D., G.I. Velez, Y.S. Diaz, and S.S. Sanchez (2009). Neutralization and addition of sweetening effect in physicochemical, microbiological and sensory properties of buffalo milk arequipe. Vitae-Revista De La Facultad De Quimica Farmaceutica 16: 201207.

AOAC (2010). Association of Official Analytical Chemists. Metode of Analysis. 15 ${ }^{\text {th }}$ Edition. Arlington. Virginia PP.1230.

Aspilcueta-Borquis, R.R., F.R.A. Neto, F. Baldi, D.J.A. Santos, L.G. Albuquerque, and H. Tonhati (2012). Genetic parameters for testday yield of milk, fat and protein in buffaloes estimated by random regression models. J. Dairy Res. 79: 272-279. https://repositorio.unesp.br/handle/11449/497 $\underline{0}$

Coroian A., S. Erler, C.T. Matea, V. Miresan, C. Raducu, C. Bele, and C.O. Coroian (2013). Seasonal changes of buffalo colostrum: physicochemical parameters, fatty acids and cholesterol variation. Chem. Central J. 7: 2-9. https://link.springer.com/article/10.1186/1752 $\underline{-153 X-7-40}$ 
Febrina L. (2010). Analisis usaha ternak kerbau pada ketinggian tempat yang berbeda di Provinsi Sumatera Barat. Tesis Program Pascasarjana Universitas Andalas, Padang.

Geantaresaa, Ergina \& FM Titin Supriyanti (2010). Pemanfaatan Ektrak Kasar Papain Sebagai Koagulan Pada Pembuatan Keju Cottage Menggunkan Bakteri Streptocochus termophillus, Lactococus laktis, dan Leuconostoc mesentroides. Jakarta: Jurnal Sains dan Teknologi Kimia. http://blog.ub.ac.id/febrina/files/2012/06/PEM ANFAATAN_EKSTRAK KASAR_PAPAIN pdf

Heller KJ, Bockelmann W, Schrezenmeir J., \& de Verse M. (2008). Cheese and Its Potential as a Probiotic Food. In: Farnworth ER. (Ed). Hanbook of Fermented Funcional Foods. 2nd ed. US: CRC Pr

Han X.L., F.L. Lee, L. Zhang, and M.R. Guo (2012). Chemical composition of water buffalo milk and its low-fat symbiotic yoghurt development. Functional Foods in Health and Disease 2(4): 86-106.

Hofi M. (2013). Buffalo milk cheese. Buffalo Bull. 32: $355-360$.

Komar N., la. C. Hawa \& P. Rika (2009). Karasteristik termal keju mozzarela (Kajian konsentrasi asam sitrat). Jurnal Teknologi Pertanian 10 (2): 78-87.

Muthalib H.A. (2006). Potensi sumber daya ternak kerbau di Nusa Tenggara Barat. Lokakarya Nasional Usaha Ternak Kerbau Mendukung Program Kecukupan Daging Sapi, Sumbawa, 4-5 Agustus 2006. Puslitbang Peternakan, Bogor. hlm. 64-72.

Mustrini I, Mappiratu \& Nurakhirawati (2016). Utilization of Sap Biduri in The Production of Albumin Fish Cork (Ophiocephalus striatus). Kovalen. 2(3):24-32.)

Otaviano A.R., H. Tonhati, J.A.D. Sena, and M.F.C. Muñoz (2005). Kappa-casein gene study with molecular markers in female buffaloes (Bubalus bubalis). Gen. Mol. Biol. 28(2): 232241.

Rosati A. and L.D. van Vleck (2002). Estimation of genetic parameters for milk, fat, protein and mozzarella cheese production for the Italian river buffalo Bubalus bubalis population. Livestock Prod. Sci. 74: 185-190. https://www.sciencedirect.com/science/article/ abs/pii/S0301622601002937

Saleh, E. (2004). Dasar pengolahan susu dan hasil ikutan ternak. Program Studi Produksi Ternak. Fakultas Pertanian Universitas Sumatera Utara.

https://d1wqtxts1xzle7.cloudfront.net/333566 49/1_5

Susanti S.P. (2005). Karakterisasi Enzim Protease Dari Getah Tanaman Biduri (Calotropis Gigantea) Hasil Ekstraksi Menggunakan Amonium Sulfat. Skripsi. Jurusan Teknologi Hasil Pertanian Fakultas Teknologi Pertanian Universitas Jember. https://repository.unej.ac.id/handle/12345678 $\underline{9 / 18582}$

Senosy, W., \& Hussein, H. A. (2013). Association among energy status, subclinical endometritis postpartum and subsequent reproductive performance in Egyptian buffaloes. Animal reproduction science, 140(1-2), 40-46. https://www.sciencedirect.com/science/article/ abs/pii/S0378432013001590

Amurita, N., \& Sustiyah, A. (2014). Total bahan padat, kadar protein, dan nilai kesukaan keju mozarella dari kombinasi susu kerbau dan susu sapi. Jurnal Aplikasi Teknologi Pangan, 3(4). http://jatp.ift.or.id/index.php/jatp/article/view/ $\underline{114}$

Steel R.G.D \& J.H. Torrie. (2015). Prinsip Dan Prosedur Statistika. Penterjemah Bambang Sumantri. Gramedia Pustaka, Jakarta

Sunarya H, A. M. Legowo and P. Sambodho (2016). The Concentration of Water, Fat and Texture of Mozzarella Cheese Made of Buffalo and Cow's Milk and It Is Combination. Animal Agriculture Journal 5(3): 17-22.

Sugitha I.M., N.N.Puspawati., I.W.R.Widarta, \& S.Miwada. (2013). Identifikasi Komponen Senyawa Aktif Pada Kulit Batang Tanaman Rampelas (Ficus ampelas) Sebagai Koagulan Alami Pada Pembuatan Keju Lunak Tradisional (Soft cheese). Laporan Hibah Penelitian Grup Riset, Universitas Udayana.

USDA (2001). Spesification for Cottage Cheese and Dry Curd Cottage Cheese. http://www.ams.usda.gov/ amsv1.0/getfile? Ddocname =steldev3004550. Diakses 29 November 2020.

Wulandani B.R.D. (1995). Pengaruh Konsentrasi Getah Clotropis Gegantea Terhadap 
Kekentalan Air Susu Secara Tradisional Di Lombok. (juara III LKIR LIPI-TVRI tahun 1995).

Witono Y. (2007). Isolasi dan Karakterisasi Enzim Protease dari Getah Tanaman Biduri. Jurnal Teknologi Hasil Pertanian. 1(1): 1- 14.

Yilmaz O., M. Ertugrul, and R.T. Wilson (2012). Domestic livestock resources of Turkey water buffalo. Trop. Anim. Health Prod. 44: 707714.

Zulbardi M. (2002). Upaya peningkatan produksi susu kerbau bagi ketersediaan dan mempertahankan potensi dadih. Prosiding Seminar Nasional Teknologi Peternakan dan Veteriner. Puslitbang Peternakan, Bogor. hlm. 186-189. 